\title{
Correlation of QWL Factors with Employee Satisfaction in Manufacturing Sector
}

\author{
${ }^{1}$ Ashwini. J, ${ }^{2}$ Prof. D. Anand \\ ${ }^{1}$ Research Student \\ ${ }^{2}$ Bahadur Institute of Management Science,UOM,Mysore
}

\begin{abstract}
Work life balance is a crucial factor for workers to contribute to the growth of the organization as well for their own wellbeing. The purpose of this study was to evaluate the impact of quality of work life factors on the overall satisfaction of the employees. A sample of 154 employees from manufacturing sector was collected and analysed objectively. Seven quality of work life factors were tested to study their relationship with the overall satisfaction of the employees. The data was tested for reliability by evaluating the Cronbach's alpha value and validity was checked by factorial analysis. Job satisfaction emerged to be the most important factor, followed by adequate and fair compensation. All the factors were positively correlated with the overall satisfaction. Organizations can benefit from the findings of this research by interweaving quality of work life into the policies and procedures for the overall development of the organization.
\end{abstract}

Key words: $Q W L$, manufacturing sector, overall satisfaction, job satisfaction, $Q W L$ factors

\section{Introduction}

Researchers as well as practitioners are interested in the quality of work life (QWL) of the workers in the manufacturing sector, as the jobs in this sector are routine and repetitive; involve conventional technology, less creative and innovative, thus resulting in disinterest among workers. Concurrently, manufacturing industries are not free of challenges; they face, if not, more challenges including high cost for raw materials, absence of corporate cultures, weak enforcement of rules and regulations, poor financial management, operational inefficiencies, etc., which creates friction between the employees and the management [1],[2]. The dissatisfaction among the employees is expressed as low productivity and low capacity utilization among the employees leading to an imbalance in the QWL.

The introduction of QWL concept by Louis Davis examined the relationship between the performance and the job satisfaction of the employees at the workplace and explained wellness quotient in an individual's life[3]. Overall, the favourableness or unfavourableness of a work place deals with the relationship between the workers and the management [4]. In the present situation, job satisfaction is derived from the balanced life an employee has than just the monetary value of the job. The employers therefore should consider the job seekers as resources that must be treated with more humane attitude. The jobs of the present day demand restructuring and remoulding to suit the needs of the workers, keeping in view the socio-economic and technological progress of the current world. Najundeshwarswamy and Swamy[5] emphasise that QWL is a "movement that is used to bring changes in the socio-technical nature of the jobs and consists of a large variety of constructs like good social circles, more employee friendly schemes, role in decision making, more powers to the employee and team performance."Rapid progress in technology has augmented the degradation of manpower, skill, estrangement and objectification of labor under the Taylorist influences [6]. Therefore, QWL factors that are involved in achieving a congenial work environment including resources, functionality, and the mutual benefits must be realized between the management and employees. Consequently, QWL would help in achieving increased employee performance and productivity, higher morale, decreased employee harassment, lower absenteeism, decreased burnout and pressures, and increased staff retention.

\section{Related Work}

The onset of QWL started as a revolutionary process that was aimed in improving the working conditions of the employees in the organizations. The organizations are known to function in a specific cultural model and are affected by the values and beliefs of the people in the local regions. Thus the constructs for the QWL will vary from one region to another and from country to country. The concept of QWL in India consists of social and monetary aspects that further impact the changes occurring in the organizations of large and small enterprise which make use of human resources [7]. The emergence of new urban educated worker class and a more aware and vociferous workforce expect treatment of employees in a more humane manner and a methodical approach to address workers' problems. Many companies in India have implemented the concept of QWL in their people management policies. It has been reported that such companies have shown greater interest and more effective results in terms of job enrichment, active involvement of worker in work-related decision 
making, flexibility in working arrangements, financial support for higher education, leave for special occasions like exam preparation, marriage, etc.

Governmental policies and schemes have resulted in emergence of a more developed industrial front in India leading to better standards and working conditions that promise more employability for the jobseeker. The manufacturing sector has seen a wave of changes in the last half a century due to liberalization and globalization and advancement in modern technology. Refinement in policies have introduced more flexible hours of work, job security, perks, health benefits, etc., to the employee.

Being considered as monotonous and repetitive without high intellectual involvement, manufacturing jobs produces boredom that translates into dissatisfaction, low productivity and revenue loss to the organization.Therefore, the organizations need to critically examine themselves to establish patterns that would allow managing of people and organizations to adequately face challenges of changing times. Mankidy[8] studied the QWL and inferred that "the more positive the industrial relations processes, the greater the possibility of improved QWL." He stated that the positive industrial relations could ensure more flexible hours of work, better income prospects, employment encumbrances; a good work environment, satisfaction at work place, growth prospects, and better involvement of employees in decision making thus creating a higher and better QWL for the workers .

In many of the manufacturing sectors, workers were unhappy with income, for example, this was true among the textile industry employees [9] and Kerala industrial estate workers [10] though they expressed satisfaction in relation to working conditions. However, Kanagalakshmi and Devi [11] on investigating the condition of the workers from textile industry found a significant relationship between QWL and work conditions in the industries. On the contrary, a study among the in textile industries of Iran cited poor working conditions as the reason for absenteeism among workers. Kavoussiet al.[12]opined that this could be changed by improving the quality of working life as absenteeism had widespread consequences across the factory. A similar study conducted by Haque[13] revealed that QWL is positively related to performance and negatively correlated to absenteeism.

Job and working environment dimensions was found to be most valid QWL factor that contributed to the job satisfaction in sugar mills in India Das.Jayarama[14] studied the QWL and job satisfaction of workers in paper and pulp industries in Dindigul, in Tamil Nadu, India and found that workers perceived factors like 'satisfaction, good work environment, security and recognition' to play a role in attaining QWL.

Manufacturing sector employees, in particular, are vulnerable to occupational hazards that affect their health. Organizations can achieve higher productivity and thus generate higher profits if the health and wellbeing of the employees are maintained. Balachandar et al.[15] noted that the employee health can be maintained well when all the basic necessities are adequately provided.

In terms of difference between work life balance in private and public sector, Wadud[16] observed a significantly higher QWL among the private sector women employees than their counterparts in the public sector which was also supplemented with the result indicating older and more experienced groups had greater perception of QWL than their younger and lesser experienced counterparts. Another study [17] also produced a similar observation wherein private sector fared well in comparison with public sector manufacturing companies. In contrast, the study of Suri et al. [18] claims neither public sector nor private sector organisations showed interest to improve or modify the design at the workplaces, although it was evident that the organisations preferred system-wide practices rather than isolated experiments that alienated certain sections or departments.

Sirgy et al. [19] emphasize that the most pertinent factors in quality of working life is to be satisfaction related to job, work environment, the treatment meted out by supervisors, training programs, and organizational commitment towards employee welfare. Depending on how an organization attracts, inspires, develops and retains people, an organization either succeeds or fail.

\section{Research Objectives}

This study was aimed at exploring the overall satisfaction of workers from manufacturing sector and the factors influencing the quality of work life among these workers. An attempt was also made at finding the relationship between QWL factors with job satisfaction.

\section{Research Design And Methodology}

The research was designed to evaluate the QWL factors that are responsible for overall satisfaction among the employees of manufacturing and to analyse the possibility of these factors bringing about changes in the working conditions in the organizations. The study used a positivist approach and consisted of the deductive analytical techniques given by different researchers to maximize the advantages of the analysis [20].

A simple random sampling method was used to collect primary data from 154 workers from manufacturing sector using a questionnaire. The constructs used in the questionnaire were job satisfaction, work 
load, opportunity for growth, training and development, adequate and fair compensation, safe and healthy working conditions, and social integration [21],[22]. The items in the constructs were measured using sevenpoint Likert scale ranging from strongly disagree (1) to strongly agree (5). Demographic details of the respondents were also collected through the questionnaire. A pre-test was conducted with 50 respondents to check the reliability and validity of the questionnaire. Those participated in the study were comfortable in using the questionnaire.

\section{Results And Discussions}

The demographic data indicated that the maximum numbers of respondents were male (81\%) above 30 years of age. The gender parity was as expected as most of the manufacturing companies employ more men than women, in addition the results show that manufacturing jobs are least preferred by women. A majority of the respondents $(71 \%)$ were married, validating the responses of this study, as balancing of work life refers to maintaining equanimity between the responsibilities at work and home. These respondents were able to relate well to the constructs mentioned in this study. More than $70 \%$ of the respondents had at least a degree and $50 \%$ of them were junior staff, while $42 \%$ were either managers or senior managers and $71 \%$ had 10 or more years of overall experience drawing Rs. 20,000 or more salary per month (56\%). More than $75 \%$ had three or more years of tenure in the organization. The demographic details of the respondents clearly indicate that they qualify to give opinions about the QWL constructs used in this study (Table 1).

Table1. Demographic details of the respondents

\begin{tabular}{|c|c|c|c|c|}
\hline & Frequency & Percentage & Mean & SD \\
\hline Age & & & \multirow{4}{*}{2.0649} & \multirow{4}{*}{0.7469} \\
\hline $20-30$ yrs & 38 & 25 & & \\
\hline $31-45$ yrs & 68 & 44 & & \\
\hline$>46$ & 48 & 31 & & \\
\hline \multicolumn{3}{|l|}{ Gender } & \multirow{3}{*}{1.1883} & \multirow{3}{*}{0.3922} \\
\hline Male & 124 & 81 & & \\
\hline Female & 30 & 19 & & \\
\hline \multicolumn{3}{|l|}{ Marital Status } & \multirow{3}{*}{1.7208} & \multirow{3}{*}{0.4501} \\
\hline Single & 44 & 29 & & \\
\hline Married & 110 & 71 & & \\
\hline \multicolumn{3}{|l|}{ Qualification } & \multirow{4}{*}{1.8571} & \multirow{4}{*}{0.7621} \\
\hline Graduate & 57 & 37 & & \\
\hline Post Graduate & 62 & 40 & & \\
\hline Diploma & 35 & 23 & & \\
\hline \multicolumn{3}{|l|}{ Designation } & \multirow{5}{*}{2.4610} & \multirow{5}{*}{0.7849} \\
\hline Fresher & 11 & 7 & & \\
\hline Junior & 78 & 51 & & \\
\hline Manager & 48 & 31 & & \\
\hline Senior manager & 17 & 11 & & \\
\hline \multicolumn{3}{|l|}{ Experience } & \multirow{5}{*}{3.0784} & \multirow{5}{*}{1.0357} \\
\hline$\leq 1 \mathrm{yr}$ & 16 & 10 & & \\
\hline $2-5 \mathrm{yrs}$ & 29 & 19 & & \\
\hline $6-10$ yrs & 37 & 24 & & \\
\hline$>10$ yrs & 72 & 47 & & \\
\hline \multicolumn{3}{|c|}{ Income (monthly in Rs.) } & \multirow{5}{*}{2.5390} & \multirow{5}{*}{1.1326} \\
\hline$\leq 10,000$ & 34 & 22 & & \\
\hline $11,000-20,000$ & 49 & 32 & & \\
\hline $21,000-30,000$ & 26 & 17 & & \\
\hline$>30,000$ & 45 & 29 & & \\
\hline \multicolumn{3}{|c|}{$\begin{array}{l}\text { Tenure with current } \\
\text { organization }\end{array}$} & \multirow{5}{*}{3.2338} & \multirow{5}{*}{1.0213} \\
\hline$\leq 1 \mathrm{yr}$ & 15 & 10 & & \\
\hline $1-2$ yrs & 21 & 14 & & \\
\hline $3-5 \mathrm{yrs}$ & 31 & 20 & & \\
\hline$>5 \mathrm{yrs}$ & 87 & 56 & & \\
\hline
\end{tabular}

\section{Reliability analysis}

Replication capability of the data obtained is essential for any test to be called successful. Reliability tests checks to what extent the findings of the research can be replicated, in case if the research is replicated using the same methodology of research [23]. In essence, it refers to the extent to which measurements are free from error, thus producing consistent results. It checks for internal consistency of the scale that measures the extent to which the items are similar. In other words, the procedures (or the items) assess the same skill, characteristic, or quality. Cronbach's alpha is a coefficient of internal consistency. It is an important measure of 
the reliability of a psychometric method. As the correlation between the item increases, Cronbach's alpha will also increase. Cronbach's alpha of 0.7 or more is recommended to show high internal consistency [24], [25]. In the present study, Cronbach's alpha value for different constructs ranged from 0.620 to 0.928 indicating a high internal consistency among the items (Table 2). The questionnaire was first tested by conducting a pilot study which had tested its validity.

Table 2: Reliability analysis

\begin{tabular}{|l|c|c|}
\hline \multicolumn{1}{|c|}{ Dimensions } & N & Cronbach's Alpha \\
\hline Job Satisfaction & 12 & 0.928 \\
\hline Opportunity for growth & 5 & 0.854 \\
\hline Work Load & 3 & 0.780 \\
\hline Social integration in the work organization & 3 & 0.602 \\
\hline Safe and healthy working conditions & 2 & 0.849 \\
\hline Adequate and Fair Compensation & 9 & 0.911 \\
\hline Training and development & 4 & 0.872 \\
\hline
\end{tabular}

Despite the correctness of the procedure employed, some argue that it is impossible to replicate the studies exactly the same way, as the conditions of the studies at that time may vary, based on which the data collected may also vary leading to deviation in results [26], [27]. Hence, frequently, it can be considered as an unrealistic demand made on the research results. Despite these arguments, the reliability can be increased through reflexivity, which is "showing the audience of research studies as much as possible of the procedures that have led to a particular set of conclusions" [27].

\section{Factor loadings}

Construct validity tests whether an agreement exists between the theoretical concepts proposed and a specific measuring procedure or device. In other words, validity refers to the extent to which data collection procedure measures accurately that it is supposed to measure [28].

Factor analysis is a statistical test employed to identify a few of the factors that can be used to represent relationships among sets of inter-related variables. Factor analysis was used in this study to check for the construct validity of the survey questionnaire used and to evaluate factors that will have an influence on the QWL of the workers in the manufacturing sector. Principal component extraction method with Varimax rotation was used to extract the factors from the survey responses. According to Straub [29], factors having an Eigen value more than 1 and loading of at least 0.40 is considered to be an acceptable result for Principal Component Analysis (PCA). The results of the factor analysis are depicted in Table 2. Sampling adequacy was tested through the Kaiser-Meyer-Olkin (KMO) measure. A value of 0.888 was obtained, which is much higher than the commonly accepted limit of 0.60 . Thus, it is confirmed that the sample size was adequate to apply factor analysis on the data.

Consequently, the value of the test statistic for sphericity[30] was large which was calculated based on Chi-squared transformation of the correlation matrix determinant. Bartlett's test of sphericity was significant, thus affirming the factorability of the correlation matrix with a high significance level (0.000). From the Bartlett's test of sphericity, it is shown that the variables within factors are correlated with each other. Table 3 provides the results obtained for KMO and Barlett's test.

Table 3: KMO and Bartlett's Test

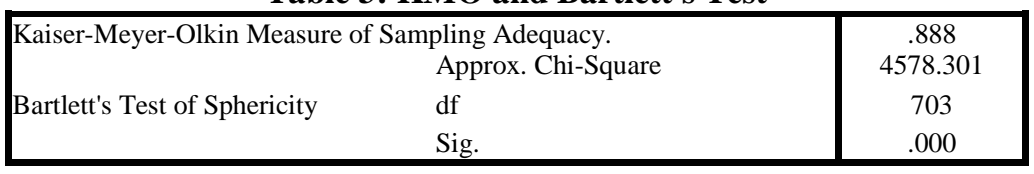

The Rotated Component Matrix shows how the retained, rotated components load on each variable. In this study, the retained factors have loaded on seven different components. This justifies the constructs that we have used are appropriate. 
Table 4. Factor Loadings

\begin{tabular}{|c|c|c|c|}
\hline & Factor loadings & $\%$ variance & $\begin{array}{l}\% \text { Cumulative } \\
\text { variance }\end{array}$ \\
\hline \multicolumn{2}{|l|}{ Job satisfaction } & 41.760 & 41.760 \\
\hline Work timings and shifts are scientifically scheduled & .741 & & \\
\hline $\begin{array}{l}\text { There is no discrimination of any type (social, racial, religious, } \\
\text { sexual,etc) }\end{array}$ & .691 & & \\
\hline $\begin{array}{l}\text { I am happy/satisfied with my teams and colleagues commitment to } \\
\text { work }\end{array}$ & .683 & & \\
\hline There is a system to resolve any disputes internally & .672 & & \\
\hline I am ready to work here till my retirement & .651 & & \\
\hline I feel proud to be identified with my company & .638 & & \\
\hline $\begin{array}{l}\text { There is a harmonious relationship between Management and the } \\
\text { Employees }\end{array}$ & .631 & & \\
\hline I am satisfied with the freedom to make decisions at my level & .620 & & \\
\hline My views are taken into account in resolving work related problems & .619 & & \\
\hline The technology used in my job is the best in the Industry & .577 & & \\
\hline $\begin{array}{l}\text { My views are considered in corporate planning, research and } \\
\text { development }\end{array}$ & .533 & & \\
\hline $\begin{array}{l}\text { There is no ambiguity about my authority and responsibility on the } \\
\text { job }\end{array}$ & .433 & & \\
\hline \multicolumn{2}{|l|}{ Adequate and fair compensation } & 8.009 & 49.768 \\
\hline $\begin{array}{l}\text { Organization pays adequate and fair compensation for all its } \\
\text { employees depending on the work they do }\end{array}$ & .772 & & \\
\hline The salary I am getting is commensurate with my abilities & .734 & & \\
\hline My salary is commensurate with my efforts and contribution & .637 & & \\
\hline My financial needs are fulfilled adequately by my pay & .588 & & \\
\hline Fringe benefits given to us is par with others in the Industry & .564 & & \\
\hline The retirement benefits provided to workers is reasonable & .508 & & \\
\hline $\begin{array}{l}\text { The extra benefits (transport, doctor, etc) that the company offers are } \\
\text { adequate }\end{array}$ & .477 & & \\
\hline \multicolumn{2}{|l|}{ Opportunity for growth } & 5.978 & 55.746 \\
\hline Performance appraisal system / method in my company is fair & .871 & & \\
\hline My rewards are linked to my performance & .829 & & \\
\hline Work environment motivates me to do my work better & .602 & & \\
\hline $\begin{array}{l}\text { My company encourages its employees to take higher studies and } \\
\text { proficiency development }\end{array}$ & .532 & & \\
\hline I have ample opportunity to use and develop skills and capabilities & .529 & & \\
\hline \multicolumn{2}{|l|}{ Training and development } & 4.633 & 60.379 \\
\hline $\begin{array}{l}\text { The training programs helps in achieving the required skill for } \\
\text { performing the job efficiently }\end{array}$ & .817 & & \\
\hline Training have helped me to do my job better & .781 & & \\
\hline Training is given on regular intervals to develop our skills & .770 & & \\
\hline I am given adequate training to do the job better & .535 & & \\
\hline \multicolumn{2}{|l|}{ Work Load } & 3.861 & 64.239 \\
\hline The work I do matches with my ability & .752 & & \\
\hline The work load given is reasonable and attainable & .651 & & \\
\hline Workload given to me can be easily done & .546 & & \\
\hline \multicolumn{2}{|l|}{ Safe and healthy working conditions } & 3.074 & 67.314 \\
\hline $\begin{array}{l}\text { Company provides good security equipment and health care } \\
\text { measures }\end{array}$ & .683 & & \\
\hline Organization gives high priority for the safety of its workers & .628 & & \\
\hline \multicolumn{2}{|l|}{ Social integration in the work organization } & 2.705 & 70.019 \\
\hline $\begin{array}{l}\text { My company cares not only its employees, but goes beyond it to } \\
\text { reach their family too }\end{array}$ & .593 & & \\
\hline My family knows about my job and my company's business & .552 & & \\
\hline There is a sense of belongingness among all my colleagues & .543 & & \\
\hline
\end{tabular}

Factor analysis extracted seven factors with Eigen value more than 1 that explained $70 \%$ of the variability of the data. The extracted factors were then rotated using Varimax (variance maximising method) rotation. These rotated factors with their variable constituents and factor loadings are given in Table4, for better reading of the results factor loadings below 0.40 are suppressed in the table.

\section{Factor 1: Job Satisfaction}

Job satisfaction emerged out to be the most important factor with 13 variables loaded on it. Job satisfaction contributed to $41.8 \%$ of the variation in the data. Job satisfaction among employees is considered as a predominant factor that relates to the health of an organization. Job satisfaction is associated with QWL and is imperative to reduce turnover rate, absenteeism, coming late for work and negative feelings. At the same time, it increases the helping tendency among the employees and extends it to customers [31]. If left unattended reduced 


\section{Factor 2: Adequate and Fair Compensation}

Adequate and fair compensation was considered as an important factor contributing $8 \%$ of the variation in data with seven variables loaded on it. The respondents feel that the salary that they get should be in commensuration with their abilities and contribution they make. Fringe benefits, retirement benefits and additional benefits like transport, doctor, etc. facilities should be reasonable in order for the employees to have an overall satisfaction with the company. Everyone works to earn a living which remains to be the key force that motivates to do well at work[33].It is therefore plausible that QWL is affected by the extent to which this goal is achieved. Fairness can be determined through job evaluation measures, such as job ranking, job classification and by factor comparison[34]. Concomitantly, various techniques are available to determine the supply and demand for particular skills and competencies, and for establishing average levels of compensation for these various categories, thus enabling the implementation of fair compensation levels [34]. Furthermore, benchmarks can be used to determine what proportions of the profits should be distributed to employees in different occupations and across different categories within these occupations [35], [36].

\section{Factor 3: Opportunity for growth}

Around $6 \%$ of the variation was explained by 'Opportunity for growth factor' suggesting a shift from job to career advancement. Employees focus upon the opportunities that are provided by employers to advance their careers, for example employer's support for higher studies and proficiency development. The variables in this factor focus on how the skills and capabilities of the employees can be used and developed and thereby do the work better, which, in turn, cascades into being rewarded for the application of skills[37]. Stein [38] refers to the component of progress and development which implies that the development of skills and competencies are an important contributing factor for QWL to be high. Further, an effort to improve this dimension of QWL can significantly enhance job satisfaction of the employees [39].

\section{Factor 4: Training and Development}

Training and development explained $4.6 \%$ of variation with four variables loaded on it. The employees believe that adequate training should be given as these programs help in honing the existing skills as well as acquiring the necessary new skills to do a job better. New strategies, especially in terms of skill training and development, should be developed to augment the employee participation in decision-making. Commitment from organizations to support localized activities and experiments will result in increased participation of employee in determining how to improve work. Training should in particular stretch to the appropriateskills, knowledge and attitudes that contribute to the welfare of the employees as well as the organization. Probability of increasing skills and capabilities through training can also get translated as a tool to retain employees. Further, training on organizational rules and regulations, procedures, expected performance standards from the employee and culture of the organization could ensure comfort of the employees and provide them the insights about the organization and required skills to perform their role to the expected level.

\section{Factor 5: Work Load}

Work load contributed $3.8 \%$ variation to the data with three variables. The respondents expected reasonable and attainable work load to ensure that there is no unnecessary pressure on them to perform the role to the satisfaction of their supervisors. Excess workload may burn out employees resulting in job stress and reduction in productivity.

\section{Factor 6: Safe and healthy working conditions}

This factor contributed to $3 \%$ of the variation in the data that concentrated on organization placing importance for healthcare measures and safety of its workers. Safety in workplace has predominantly become the highest operational priorities facing organisations and human resource management [40].Therefore, exposure of employees to working conditions that can adversely affect their physical and mental health should be avoided. Investing on the employees' health and safety can promote general health of the organization, concurrently leading to higher efficiency of the organization.

\section{Factor 7: Social integration in the work organization}

Social integration is an important determinant of QWL [35], [36]. Employees consider the care extended to the family by the employer as an essential part of work life balance. An in-depth understanding and a good inter-personal relationship between the organization and the employees and also among other employees create a sense of belongingness with the organization, which invariably would take the organization a long way in the path of success[41].

Correlation analysis was conducted to evaluate the pair-wise relationship between the constructs studied, such as Job satisfaction (JS), Work load (WL), Opportunity for growth (OG), Training and development 
(TD), Adequate and fair compensation (FC), Safe and healthy working conditions (SH), and Social Integration (SI). Table5 clearly indicates that the QWL factors are correlated with Overall satisfaction (OS) of the employee in the organization. From Table 4, it can be understood that maximum correlation existed between overall satisfaction and social integration $(r=0.691)$, followed by association with adequate and fair compensation $(r=$ $0.657)$ and opportunity for growth $(\mathrm{r}=0.602)$. Though training and development is crucial for overall satisfaction, it was least correlated according to the data $(\mathrm{r}=0.321)$. A similar trend was also observed by Absar et al.[42] in his study on human resource practices and job satisfaction among the manufacturing sector workers of Bangladesh. All the QWL factors were correlated with each other and with overall satisfaction which statistically significant at $\mathrm{p}=0.000$.

Table 5. Correlations matrix for QWL factors with overall satisfaction

\begin{tabular}{|l|r|r|r|r|r|r|r|r|}
\hline Constructs & OS & \multicolumn{1}{c|}{ OG } & WL & TD & FC & SH & SI & JS \\
\hline OS & 1.000 & & & & & & & \\
\hline OG & .602 & 1.000 & & & & & & \\
\hline WL & .422 & .590 & 1.000 & & & & & \\
\hline TD & .321 & .543 & .499 & 1.000 & & & & \\
\hline FC & .657 & .560 & .528 & .488 & 1.000 & & & \\
\hline SH & .584 & .441 & .477 & .363 & .654 & 1.000 & & \\
\hline SI & .691 & .558 & .477 & .484 & .575 & .540 & 1.000 & \\
\hline JS & .574 & .525 & .556 & .540 & .783 & .723 & .607 & 1.000 \\
\hline
\end{tabular}

\section{Hypothesis Testing}

The relationship between different QWL factors was tested against overall satisfaction of the employee working in a manufacturing company. Linear regression was used to test the hypotheses framed as part of this research. Simple linear regression model helps to predict the value of the dependent variable based on the independent variable. It is an important statistical test used for analyzing the relationship between the dependent variable and independent variable. In addition to making predictions, it is used to determine whether differences in the independent variables can help explain the differences in the dependent variable and quantify the degree to which the independent variable explains the dependent variable. This method is often used in the information research and is accepted to be a reliable first-generation method [43]. In this research, linear regression analysis was conducted to reveal how different factors of QWL affect the overall satisfaction of the employees in the company.

In order to test the hypotheses, several linear analyses were conducted on the variables where the average of the items in the constructs was used. Hypotheses are considered to be true when standardized coefficient $(\beta)$ are significant, i.e., the $\mathrm{p}$ value should be less than 0.05 at $95 \%$ confidence level.

The linear regression model established that the independent variables, Job satisfaction, Work load, Opportunity for growth, Training and development, Adequate and fair compensation, Safe and healthy working conditions, and Social Integration could predict the QWL of the employees working in manufacturing organizations. Job satisfaction accounted for 32.5\%; Work Load, 17.3\%; Opportunity for growth, 35.8\%; Training and development, 9.7\%; Adequate and fair compensation, $42.8 \%$; Safe and health working conditions, $33.7 \%$; and Social Integration, $47.4 \%$ of the explained variability in overall satisfaction of the employee with the company (Table 6).

Table 6: QWL predictors in relation to overall satisfaction

\begin{tabular}{|c|l|c|c|c|c|}
\hline Model & \multicolumn{1}{|c|}{ Independent Variable } & R & R Square & $\begin{array}{c}\text { Adjusted R } \\
\text { Square }\end{array}$ & $\begin{array}{c}\text { Std. Error of the } \\
\text { Estimate }\end{array}$ \\
\hline 1 & Job satisfaction & $.574^{\mathrm{a}}$ & 0.329 & 0.325 & 0.929 \\
\hline 2 & Work load & .422 & .178 & .173 & 1.028 \\
\hline 3 & Opportunity for growth & .602 & .363 & .358 & .906 \\
\hline 4 & Training and development & .321 & .103 & .097 & 1.075 \\
\hline 5 & $\begin{array}{l}\text { Adequate and fair } \\
\text { compensation }\end{array}$ & .657 & .432 & .428 & .855 \\
\hline 6 & $\begin{array}{l}\text { Safe and healthy working } \\
\text { conditions }\end{array}$ & .584 & .342 & .337 & .921 \\
\hline 7 & Social Integration & .691 & .477 & .474 & .820 \\
\hline
\end{tabular}

Using the $\mathrm{F}$ value, it can be observed how well the regression model fits the obtained data. The $\mathrm{F}$ value indicates whether the regression model results in a statistically significant and better prediction of the dependent variable, i.e., overall satisfaction of the employee with the company, than if it was just checked with the mean value.

It is clearly understood that the research model is highly statistically significant at a confidence level of $95 \%$. The $\mathrm{p}$ value less than 0.00 proves that the regression model is valid. 
Table 7: F values of the regression model

\begin{tabular}{|l|l|c|c|}
\hline Model & \multicolumn{1}{|c|}{ Independent Variable } & F value & Significance \\
\hline 1 & Job satisfaction & 74.634 & 0.000 \\
\hline 2 & Work load & 32.972 & 0.000 \\
\hline 3 & Opportunity for growth & 86.438 & 0.000 \\
\hline 4 & Training and development & 17.406 & 0.000 \\
\hline 5 & Adequate and fair compensation & 115.626 & 0.000 \\
\hline 6 & Safe and healthy working conditions & 78.831 & 0.000 \\
\hline 7 & Social Integration & 138.851 & 0.000 \\
\hline
\end{tabular}

Organizations should therefore insist on developing human capacities by concentrating on skill development programs, training programs, and opportunity to grow. Empowerment of employees can significantly improve employee motivation [44], [45]. In addition, skill development has direct relationship with the increase in performance-based incentives and job promotion as well as job security. Thus, the development of skill among the employees would increase the productivity and have greater impact on the job satisfaction of the employees (Table 7).

\section{Conclusion}

The study conclusively demonstrated that all the QWL factors studied had significant impact on the overall satisfaction of the employees of the manufacturing sector. It is an undisputed fact that satisfied employees are productive employees and contribute to the growth of the organization. They also take the initiative to change the work environment to benefit themselves and remain as a source of motivation for others. Therefore, organizations should continuously strive to perceive QWL as a new way of thinking at the enterprise level, instead of as a set of principles and techniques that produce intermittent result. QWL should be interwoven with the policies, procedures, and management to form a cohesive philosophy of the organization.

\section{Reference}

[1] D. R. Adhikari, Developments in the management of human resources in Nepal (Innbruck: Leopold-Franzens-University, Innsbruck, 2000).

[2] D. Pant, and D. Pradhan, Garment Industry in Nepal, in G. Joshi (Ed.), Garment Industry in South Asia Rags or Riches? (New Delhi: SAAT-ILO, 2002).

[3] C. C. Hian, and W. O. Einstein, Quality of work life (QWL): What can unions do? S.A.M. Advanced Management Journal, 55(2), $1990,17-22$.

[4] M. Sankar, and R. Mohanraj, Quality of work life sustain robust work culture: a field experience sampling study on sago industry, International Journal of Advanced Research, 1(6), 2014, 269-273.

[5] T. S. Nanjundeswaraswamy, D. R. Swamy, A literature review on quality of work life and leadership styles, International Journal of Engineering Research and Applications (IJERA), 2(3), 2012, pp.1053-1059.

[6] Z. Hannif, et.al., Call Centers and the Quality of Work Life: Towards a Research Agenda, Journal of Industrial Relations, 50(2), 2008, p. 271-284.

[7] R. Indumathy, and S. Kamalraj, A STUDY on quality of work life among workers with special reference to textile industry in Tirupur district - a textile hub, International Journal of Multidisciplinary Research, 2(4), (2012).

[8] Jayakumar, and K. Kalaiselvi, Quality of work life-an overview IRJC, International Journal of Marketing, Financial Services \& Management Research, 1(10), 2012.

[9] J. Mankidy, Quality of Work Life and industrial relations: Linking the in evitables. In D. S. Saini, \& S. A. Khan (Eds.), Human Resource Management Perspectives for the New Era (New Delhi: Response Books, 2000), pp. 250-269.

[10] G. Jagatheesh, Chandran, Quality of work life in the Industrial Estates of Kerala, 2013

[11] L. Kanagalakshmi, and N. B. Devei. A Study on Perception of Quality of Work Life among Textile Manufacturing Workers in Tirunelveli, 2003.

[12] N. e. Kavoussi, The effect of unsatisfactory working condition on the epidemiology of unauthorised absenteeism in an old textile factory, Journal of Human Ecology, 1978.

[13] Haque, QWL \& Job satisfaction of industrial workers in relation to size of the organization, Bangladesh journal of psychological studies, 2(1), 1992. 43-45.

[14] S. Jayarama, A Study on Quality of Work Life of Paper \& Pulp Mill Employees in Dindigul District, Tamilnadu, India. Asian Journal of Research in Business Economics \& Management, 4(2), 2013, p1-6.

[15] G. Balachandar, N. Panchanatham and A. Arumugam, Quality of Work Life Motivating Insurance Company Officers in Tirunelveli, Outreach, 5, 2012, 202-208.

[16] N. Wadud, Job stress \& QWL among working women, Bangladesh Psychological Studies, 6, 1996, 31-37.

[17] E. M. Hoque, and A. Rahman, Quality of Working Life and job behaviour of workers in Bangladesh: A comparative study of private and public sectors, Indian Journal of Industrial Research, 35(2), 1999, 175-184.

[18] G. K. Suri, Quality of work life and productivity, conference paper, cases and proceedings (New Delhi: National Productivity Council, 1991).

[19] M. J. Sirgy, D. Efraty, P. Siegel, and D. Lee, A new measure of quality of work life (QoWL) based on need satisfaction and spillover theories, Social Indicators Research, 55, 2001. 241- 302.

[20] M.Easterby-Smith, R. Thorpe, and A. Lowe, Management research: An introduction (SAGE Publications, London, 2002). 
[21] R. E. Walton, Criteria for Quality of Working Life, in The quality of working life (Eds.) L. E. davis and A. b. Cherns (The Free Press: New york ,1975), pp. 99-104.

[22] M. M. Haque, M. T. Azim, Affective commitment and its antecedents: An empirical study in the context of Bangladesh, Paper presented at the 7th International Conference on Ethics and Quality of Work-life for Sustainable Development, Bangkok, Thailand, 2008.

[23] J. Ritchie, and J. Lewis, (Eds.), Qualitative research practice: A guide for social science students and researchers. (London: Sage, 2003).

[24] R. F. DeVellis, Scale Development: Theory and Applications (2nd ed), (Sage, 2003)

[25] J. B Kline, Psychological testing: A practical approach to design and evaluation (Sage, Thousand Oaks, 2005).

[26] C. Marshall, and G. B. Rossman, Designing Qualitative Research. (3rd ed.) (Sage Publications, Thousand Oaks, CA, 1999).

[27] C. Seale, Quality in qualitative research. Qualitative Inquiry, 5(4), 1999, 465-478.

[28] P. Saunders, A. Huynh, J. Goodman-Delahunty, Defining workplace bullying behavior professional lay definitions of workplace bullying. Int. J. Law Psychiatr., 2007, pp. 340-354.

[29] Straub, Validating Instruments in MIS Research, MIS Quarterly, 13(2), 1989, pp. 147-169.

[30] M. S. Bartlett, A note on the multiplying factors for various chi square approximations, Journal of the Royal Statistical Society, 16(Series B), 1954, 296-298.

[31] S. G. Cohen, L. Chang, and G. E. Ledford, A hierarchical construct of self- management and perceived work group effectiveness, Personnel Psychology, 50 (2), 1997, 275 - 308,

[32] J. Joseph, and S. P. Deshpande, The impact of ethical climate on job satisfaction of nurses, Health Care Management Review, 22, 1997, 76-81.

[33] M., Schreuder, and A. L. Theron, Careers: an organizational perspective (Cape Town: Juta\& Co, Ltd., 1997).

[34] R. Schuler, Managing human resources (Ohio: South Western College Publishing, 1998).

[35] C. Orpen, The conceptualization of quality of working life. Perspectives in Industrial Psychology, 7,1981, 36- 69.

[36] R. E. Walton, Quality of Working Life: what is it? Sloan Management Review, 1973,11-21.

[37] J. Bertrand, Designing quality into work life. Quality Progress, 12, 1992, 29-33.

[38] B. A. Stein, Quality of work life in action: managing for effectiveness (New York: American Management Association, 1983).

[39] A. Tabassum, T. Rahman, and K. Jahan, Quality of Work Life Among Male and Female Employees of Private Commercial Banks in Bangladesh, Int. Journal of Economics and Management, 5(1), 2011, 266 - 282.

[40] Nuñez, Outsourcing occupational safety and health: an analysis of the make or buydecision, Human Resources Management, 48 (6), 2009, 941-958.

[41] E. Kheradmund, M. Valilou, and A., L., Relationship between quality of work life and job performance. Middle East Journal of scientific research, 6(4), 2010, 317- 323.

[42] M. M. Absar, M. T. Azim, N. Balasundaram and S. Akhter, Impact of human resources practices on job satisfaction: Evidence from manufacturing firms in Bangladesh, Petroleum-Gas University of Ploiesti Bulletin, 62(2), 2010, 31-42.

[43] D. Gefen, D. W. Straub, and M.-C. Boudreau, Structural Equation Modeling Techniques and Regression: Guidelines for Research Practice, Communications of the AIS, (1:7), 2000, 1-78.

[44] R. L Mathis, and J. H Jackson, Human Resources Management, 3rd edn (Thompson, Bangalore, 2005)

[45] C. D. Fisher, L. F. Schoenfeldt, J. B Shaw, Human Resources Management (Biztantra, New Delhi, 2004). 